one of the plantations attacked produced only $\mathrm{I} 75$ pounds instead of 18,000 pounds of cocoa.

THE additions to the Zoological Society's Gardens during the past week include a Formosan Deer (Cervus tä̈vanus o), a Japanese Deer (Cervus sika \&) from Japan, two Three-striped Paradoxures (Paradoxumes trivigatus), a Great Eagle Owl (Bubo maximus) from China, presented by Capt. C. Taylor s.s. Aberdecn; a Common Fox (Canis vulpes \&), British, presented by Mr. Edward IIall ; a Bewick's Swan (Cygnus bewicki) from China, presented by Mr. Jansen; a Peregrine Falcon (Falco peregrinus) from Cyprus, presented by Dr. W. Hoad ; a Mantchurian Crane (Grus viridirostris) from North China, eighteen Spanish Blue Magpies (Cyanopolizts cooki) from Spain, an Indian Python (Python molurus) from India, two Water Rattlesnakes (Crotalus adlananleus) a Mocassin Snake (Tropidonotus fasciatus) from North America, deposited ; five African Lepidosirens (Protopterus annectans) from the River Gambia, West Africa, purchased; a Royal Python (Python regius) from West Africa, received in exchange; an Indian Muntjac (Cervulus muntjac ob), born in the Gardens.

\section{OUR ASTRONOMICAL COLUMN.}

Comet I 889 a (Brooks, July 6.) - The following elements and epliemeris for this object are by Herr Otto Knopf (Astr. Nach., No, 2916) :-

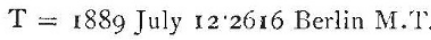

$$
\begin{aligned}
& \left.\begin{array}{rlrr}
\pi & =33^{\circ} & 7 & 5 \\
8 & = & 4 & 56 \\
8 & 4 & 56
\end{array}\right\} \text { Mean Eq. } 1889^{\circ} \circ \\
& t=5447 \\
& \log q=0.35280
\end{aligned}
$$

Errcr of middle place $(\mathrm{O}-\mathrm{C})$.

$d \lambda \cos \beta=+20^{\prime \prime} ; d \beta=-2^{\prime \prime}$.

The observations on which these elements are based were obtained at Lick, July 8 ; Vienna, July $2 \mathbf{I}$; and Dresden, July 30.

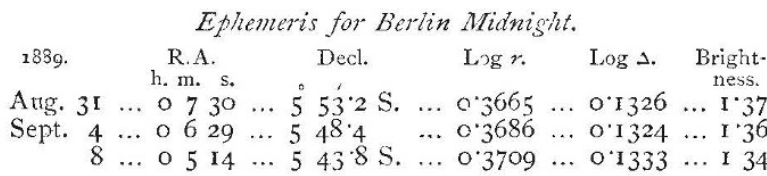

The brightness on July 8 is taken as unity.

On August I, Mr. Barnard observing at the Lick Observatory, found the comet to be composed of three distinct adjacent comets, perhaps more; and Prof. Weiss, under date August 6, reported it as fourfold.

COME'T 1889 e (DAviuson).--Dr. Becker gives the following elements and ephemeris for this comet, derived from observations made at Rome on July 26, Vienna on Aigust 4, and Dun Echt on August 15.

$$
\left.\begin{array}{rl}
\mathrm{T} & =\mathrm{I} 889 \mathrm{July} \text { 19.29538 G.M.T. } \\
\pi-8 & =34553 \quad 6^{\prime \prime} \cdot 9 \\
\Omega & =286 \quad 8 \quad 16^{\circ} \cdot 2 \\
\iota & =655959^{\circ} 7
\end{array}\right\} \text { Mean Eq } 1889^{\circ} \mathrm{O} .
$$

$$
\text { Ephemeris for Greenwich Midnight. }
$$

1889. R.A. Decl. Log $\Delta . \quad$ Log $r$. Bright-

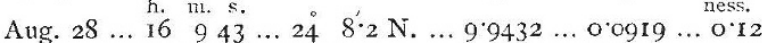

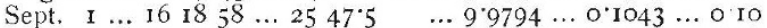
$\begin{array}{llllllllllllllllll}5 & \ldots & 16 & 27 & 38 & \ldots & 27 & 9.7 & \ldots & 0.0125 & \ldots & 0.1170 & \ldots & 0.08\end{array}$

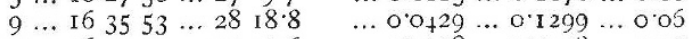
$\begin{array}{llllllllllllllll} & 13 & \ldots & 16 & 43 & 49 & \ldots & 29 & \text { I } 7.6 & \ldots & 0.0708 & \ldots & 0.1428 & \ldots & 0.05\end{array}$ $\begin{array}{llllllllllllllllll}17 & \ldots & 16 & 51 & 34 & \ldots & 30 & 8.2 & \ldots & 0 & 0966 & \ldots & 0 & 1 & 557 & \ldots & 0.04\end{array}$

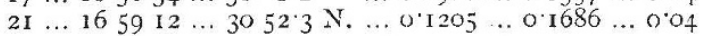
The brightness on July 22 has been taken as unity.

New Minor Planets. - Two new minor planets were discovered on August 3; the one, No. 285, by Herr Palisa at Vienna, the other, No. 286, by M. Charlois at Nice.

New Double Stars. - Mr. Burnham reports that $\eta$ Ophiuchi is a close double, the two components being of nearly equal magnitude. The present position of the fainter is angle $=274^{\circ} \%$, and distance $=\mathrm{o}^{\prime \prime} 35$. It will probably be found to be a binary of somewhat short period.

$\theta$ Cygni has a small companion at position-angle $43^{\circ} \cdot 9$, and distance $3^{\prime \prime} \cdot 62$, recently discovered by Mr. Burnham. The companion is about the fourteenth magnitude.

Stars with Remarkable Spectra. - The examination of the photographs of stellar spectra taken at Harvard College in connection with the Henry Draper Memorial has shown $D M+43^{\circ}$ No. 357 I to have a spectrum crossed by bright lines, and similar to those of the three stars discovered hy Wolf and Rayet in 1867. Two other stars, DM $+66^{\circ}$ No. 878 , and D M $+84^{\circ}$ No. $5 \mathrm{I} 6$, especially the latter, have the most strongly marked spectra of Secchi's third type which have yet been recognized, except in the case of some variables of long period.

\title{
ASTRONOMICAL PHENOMENA FOR THE WEEK 1889 SEPTEMBER I-7.
}

(FOR the reckoning of time the civil day, commencing at Greenwich mean midnight, counting the hours on to 24 , is here employed.)

\section{At Greenwich on September I}

Sun rises, 5 h. $15 \mathrm{~m}$. ; souths, I I h. $59 \mathrm{~m}$. $46^{\circ} 7 \mathrm{~s}$. ; daily decrease of southing, $18.9 \mathrm{~s}$; ; sets, $18 \mathrm{~h}, 45 \mathrm{~m}$. : right asc. on meridian, roh. $43^{\prime} \mathrm{Im}$; ; decl. $8^{\circ} 8^{\prime} \mathrm{N}$. Sidereal Time at Sunset, I 7 h. $30 \mathrm{~m}$.

Moon (at First Quarter September 2, 20h.) rises, I Ih. 59m, souths, $16 \mathrm{~h} .5 \mathrm{Om} . ;$ sets, $2 \mathrm{Ih} .3 \mathrm{Im}$ : right asc. on meridian, I 5 h. $33^{\circ} 9 \mathrm{~m}$.; decl. $15^{\circ} 29^{\prime} \mathrm{S}$.

Planet. Rises. Souths. Sets. Right asc, and declin

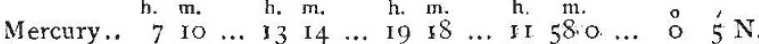
$\begin{array}{llllllllllllllllllllllllll}\text { Venus..... } & \text { I } & 33 & \ldots & 9 & 23 & \ldots & \text { I } 7 & 13 & \ldots & 8 & 6.4 & \ldots & 19 & 33 & \mathrm{~N} .\end{array}$

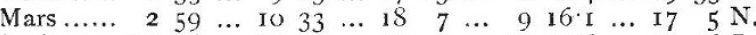
$\begin{array}{llllllllllllllllll}\text { Jupiter... } & 15 & 16 & \ldots & 19 & 9 & \ldots & 23 & 2 & \ldots & 17 & 53^{\circ} 6 & \ldots & 23 & 26 & \mathrm{~S} .\end{array}$

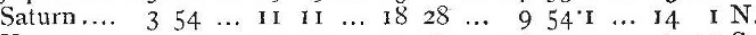
$\begin{array}{llllllllllllllllllllll}\text { Uranus ... } & 9 & 3 & \ldots & \text { I4 } & 30 & \ldots & \text { I9 } & 57 & \ldots & \text { 13 } & 13 & 19 & \ldots & 7 & \text { I2 } & \mathrm{S} .\end{array}$ $\begin{array}{llllllllllllllllll}\text { Neptune.. } 2 \text { I } & 39^{* *} \ldots & 5 & 29 & . . & \text { J3 } & \text { I9 } & . . & 4 & \text { I1 } 7 & \ldots & \text { I } 9 & 26 & \text { N. }\end{array}$ * Indicates that the rising is that of the preceding evening. Sept. $\mathrm{h}$.

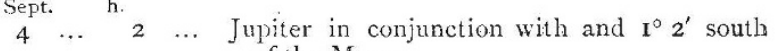
$\begin{array}{lllll}7 & \ldots & S & \ldots & \text { Neptune stationary. }\end{array}$

\section{Variable Stars.}

Star.

$$
\text { R.A. Decl. }
$$

S Arietis $\ldots . . . \quad$ i $58.7 \ldots$ I 2 o N. ... Sept. I, h. m.

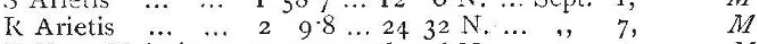

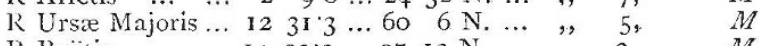
$\begin{array}{llllllllllllll}\text { R Boötis } & \ldots & \ldots & \text { I } 4 & 32.3 & \ldots & 27 & \text { I } 3 & \text { N. } & \ldots & , y & 2, & M\end{array}$ $\begin{array}{llllllllllllllll}\delta \text { Libre } & \ldots & \ldots & 14 & 55^{\circ} & \ldots & 8 & 5 & \mathrm{~S} . & \ldots & , & 5 & 0 & 22 & \mathrm{~m}\end{array}$ $\begin{array}{lllllllllllllllllll}\text { U Coronæ } & \ldots & \ldots & 15 & 13.7 & \ldots & 32 & 3 & \mathrm{~N} & \ldots & \ldots & , & 3, & 2 & \text { I } & m\end{array}$ $\begin{array}{lllllllllllllllll}\text { U Ophiuchi... } & \ldots & \text { I } 7 & 10^{\circ} 9 & \ldots & \text { I } & 20 & \mathrm{~N} . & \ldots & \text {, } & 3 . & \text { o } & 46 & m\end{array}$

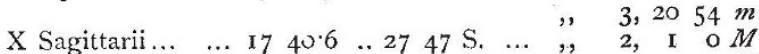

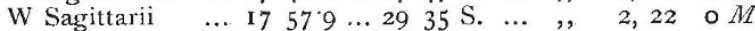

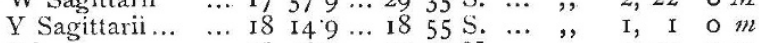

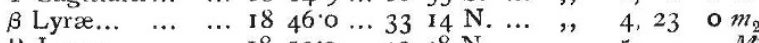

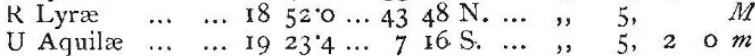

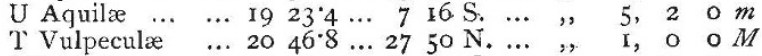

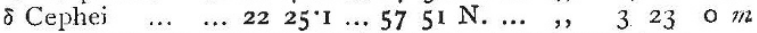
$M$ signifies maximum ; $m$ minimum ; $m_{2}$ secondary minimum.

\section{Meteor-Shozuers. \\ R.A. Decl.}

Near $\rho$ Persei

" 33 Cygni

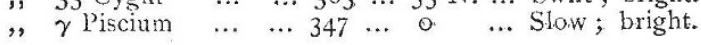

